\title{
Dynamic structure and data sets of a GIS database for geological risk analysis in the Azores volcanic islands
}

\author{
J. L. Gaspar, C. Goulart, G. Queiroz, D. Silveira, and A. Gomes \\ Centro de Vulcanologia e Avaliação de Riscos Geológicos da Universidade dos Açores, Observatório de Avaliação de Riscos \\ Geológicos, Rua Mãe de Deus, 9501-801 Ponta Delgada, Portugal
}

Received: 7 October 2003 - Revised: 4 December 2003 - Accepted: 30 December 2003 - Published: 15 April 2004

Part of Special Issue "Geo-databases for Natural Hazards and Risk Assessment"

\begin{abstract}
Geological hazards in the Azores archipelago include earthquakes, volcanic eruptions, degassing phenomena and landslides, being the cause of thousands of deaths and severe damage and loss. To reduce the impact of future events it is necessary to improve the emergency response and reinforce land-use planning, and this has given rise to the development of AZORIS, a GIS database for risk analysis in the Azores. At present this computer-based system comprises nine main dynamic data sets where elemental, monitoring and historical data are grouped in layers of first and second order. The logical structure of the database was conceived in order to facilitate interactivity between data sets and to guarantee the evolution of the system, as determined by the input and the generation of new and more detailed information. Archive organization was designed taking into account regional and local aspects of geological hazard. In order to ensure consistency of the database and the quality of the data within it, an internal process of validation was included.
\end{abstract}

\section{Introduction}

The Azores archipelago is located in the Atlantic Ocean and is formed by nine volcanic islands. Its complex geological setting is dominated by the existence of a mantle plume where the American, Eurasian and African plates meet (White et al., 1976; Searle, 1980). In the last five hundred years thirty destructive earthquakes have occurred in the region and at least twenty-eight volcanic eruptions have been reported. Landslides take place every year triggered either by seismic events or very intense rainfall episodes (Valadão et al., 2002) and volcanic gases are permanently being released in several inhabited areas (Baxter et al., 1999). Over the years landslides have been responsible for thousands of deaths and a huge amount of damages and losses (Gaspar et al., 1998).

Correspondence to: J. L. Gaspar

(jlgaspar@notes.uac.pt)
In order to minimize the impact of future events it is necessary to define and implement strategies for both land-use and emergency planning having in mind that risk increases with urban expansion. However, risk analysis is a complex subject due to the nature and variety of data and processes that need to be taken into account (Cruz-Reyna, 1996), and there is not a definitive way to deal with it. Moreover, people and authorities often find it difficult to understand risk uncertainty and do not expect to be restricted because of something that is probabilistic. To face this reality the Centre of Volcanology and Geological Risk Assessment of the Azores University decided to build a Geographic Information System (GIS) database to compile all the data required for risk assessment and management in the Azores. GIS are computer-based systems with a high potential to archive, manipulate, analyse and display georeferenced data (Aronoff, 1989) and are becoming a major tool for geological hazard analysis and risk mitigation (Coppock, 1995). Several papers have recently been published concerning the use of GIS tools for the study of geological (Salvi et al., 1999), seismological (Ganas and Papoulia, 2000), volcanological (Kauahikaua et al., 1995; Pareschi et al., 2000; Pareschi, 2002) and landslides data (Carrara et al., 1991; Carrara et al., 1995; Carrara et al., 1999; Jibson et al., 2000; Van Westen et al., 1999). When available, hazard and vulnerability data can easily be represented in a GIS and a great diversity of risk maps can then be produced following the implementation of specific predicting models.

A major difficulty for those dealing with GIS is to obtain high quality and validated georeferenced data (Carrara et al., 1995). This situation is particularly evident in the scope of risk analysis due to the diversity of data that need to be considered. Moreover, the acquisition, storage and maintenance of all this information following a high criterion of quality are critical to guarantee the accuracy and consistency of the GIS database through time. In this work we present the structure and the data sets of AZORIS, a GIS database for geological risk analysis in the Azores based on the ArcGIS ${ }^{\circledR}$ software from ESRI and installed over a Windows 2000® platform from Microsoft. 


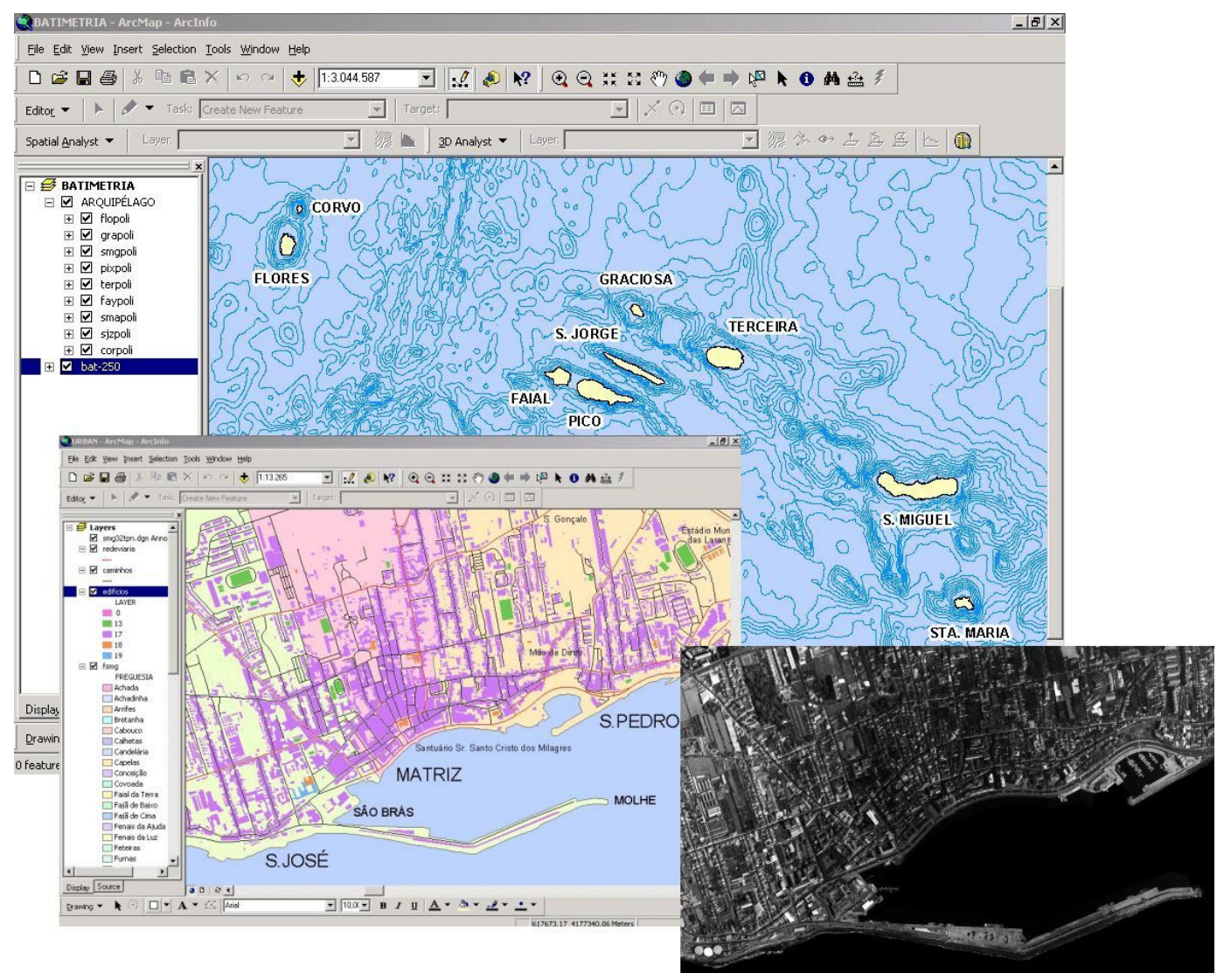

Fig. 1. AZORIS database includes geographical and socio-economic data for the Azores archipelago and municipalities.

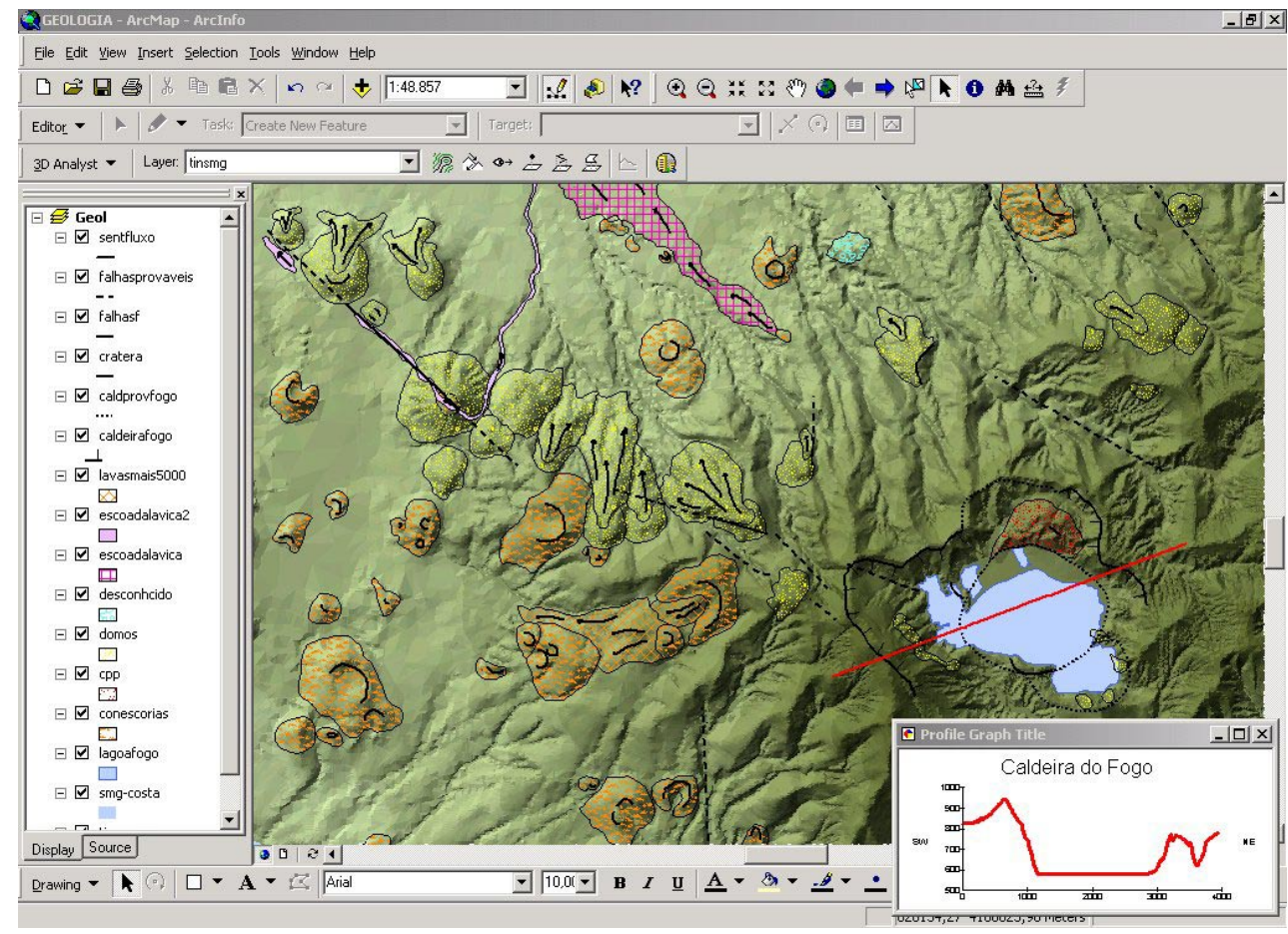

Fig. 2. Example of a display with layers from the geological and geomorphologic data sets. 




Fig. 3. Information related with the different monitoring systems as well as the data acquired are gathered in AZORIS.

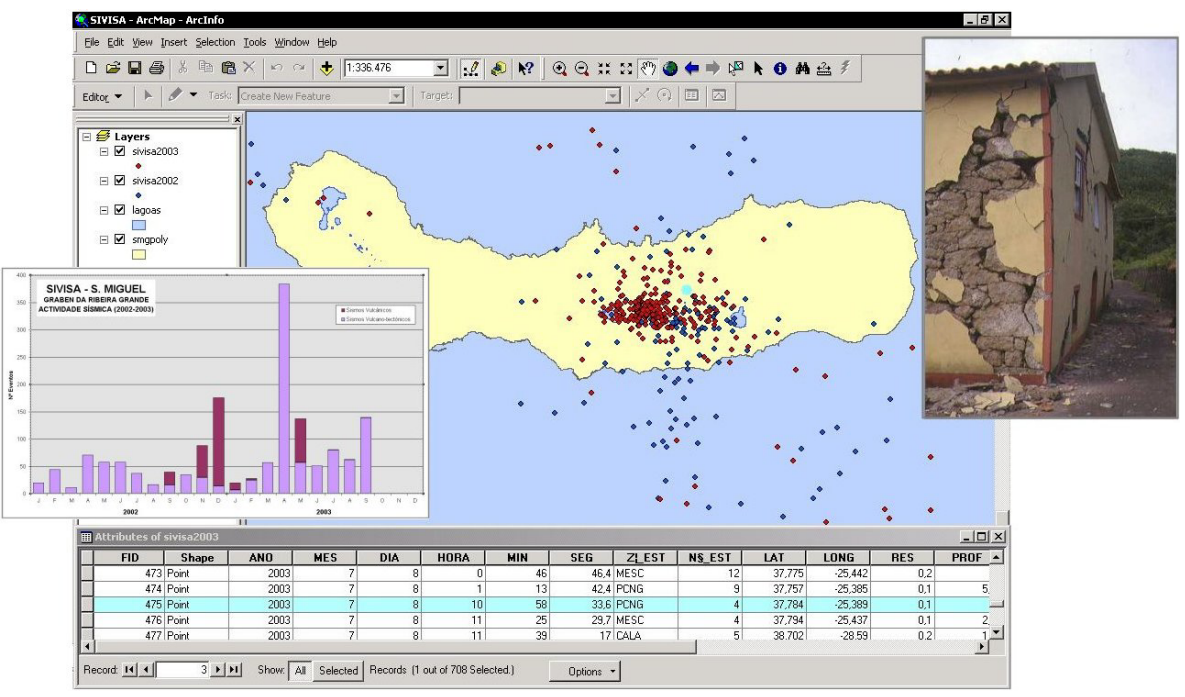

Fig. 4. Example of the spatial and temporal analyses of seismological data within AZORIS.

\section{Data sets definition}

The AZORIS database is composed of several thematic data sets defined according to the type of information. Each data set comprises several layers, which in turn can include numerous data. Due to the constant input of new and more detailed information the system was built in such a way that data can become a layer and, thus, develop into a data set without changing the physical or logical structure of the database. At this stage the available data is grouped in nine sets comprising basic, monitoring and historical information:
- Geographical and socio-economic

- Civil protection

- Geological and geomorphologic

- Landslides

- Volcanological

- Seismological

- Geodetic 

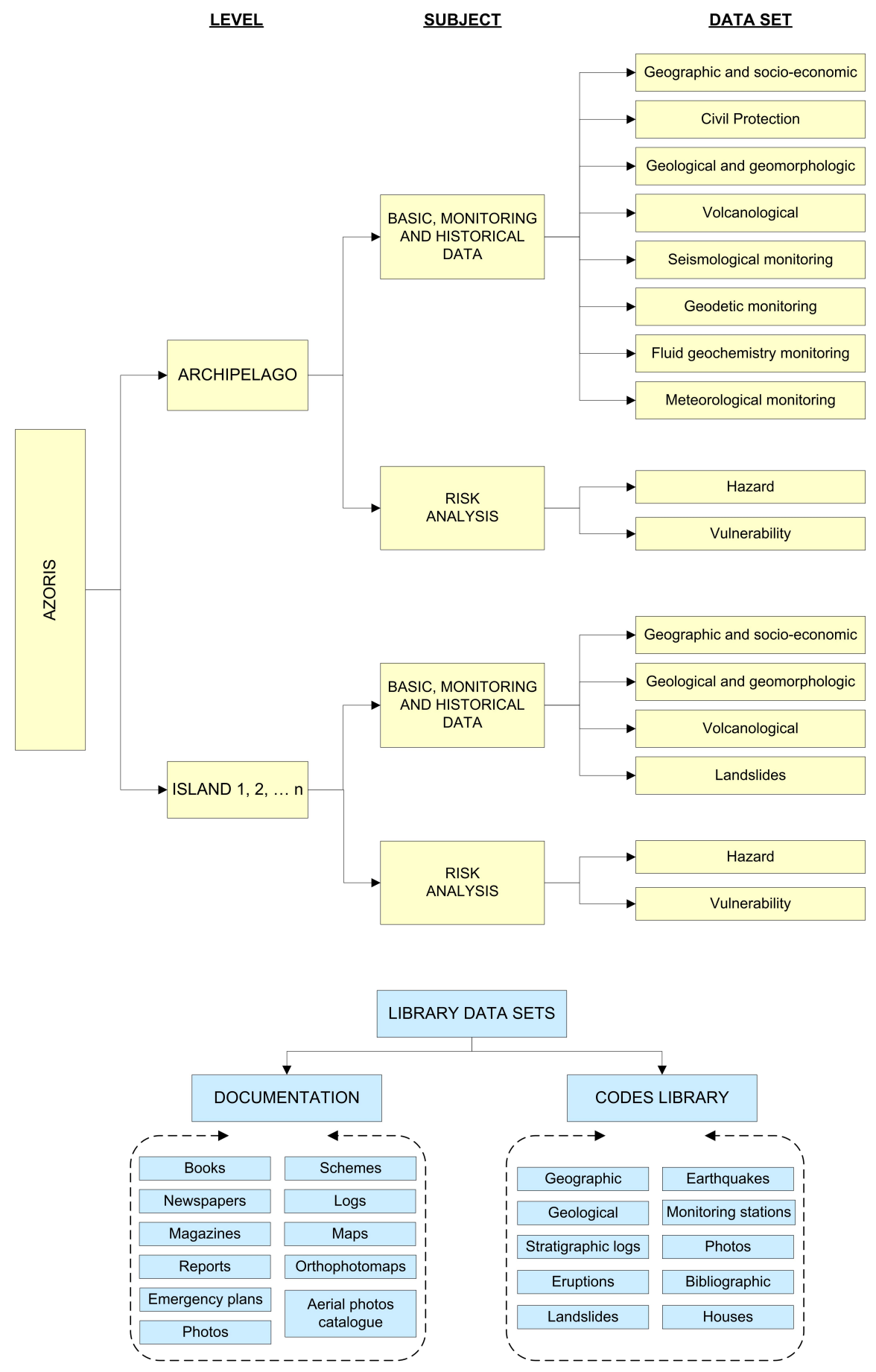

Fig. 5. Organizational scheme of the information available in AZORIS.

- Fluid geochemistry

- Meteorological

The geographical and socio-economic data set (Table 1) includes the topographic maps available for the Azores and the basic data needed for vulnerability analysis. The most recent topographic data existing for all the islands constitute the 1:25000 scale digital maps edited in 2001 by the Insti- tuto Geográfico do Exército de Portugal. Besides altitude, these maps incorporate additional information such as urban areas, roads and hydrology. The information contained in the package may be up-dated as required. Supplementary layers were added to the system, including counties and parishes administrative boundaries, population, energy and water supply systems, land-use classification and infrastructures for telecommunications (Fig. 1). For detailed studies all 
Table 1. Geographical and socio-economic data sets. Items between brackets are entered in these, or other data sets.

\begin{tabular}{|c|c|c|}
\hline Layers & Data & Features type \\
\hline Elevation contours & $\begin{array}{l}\text { Major contour lines, minor contour lines, elevation points, } \\
\text { geodetic vertices }\end{array}$ & Points, lines \\
\hline Coastlines & Zero metre contour line & Lines, polygons \\
\hline Streams & Main streams, tributary streams & Lines \\
\hline Administrative boundaries & Counties, parishes & Lines, polygons \\
\hline Location Details & $\begin{array}{l}\text { Names of islands, counties, cities, villages, parishes, localities, } \\
\text { places, lighthouses, main roads, streams, lakes, mountains, har- } \\
\text { bours }\end{array}$ & Images \\
\hline Buildings & $\begin{array}{l}\text { (Houses), historical monuments, public buildings, schools, } \\
\text { churches, hospitals, public health centres, cemeteries, (civil } \\
\text { protection headquarters), (fire department headquarters), police } \\
\text { headquarters, lighthouses }\end{array}$ & Polygons \\
\hline Houses & $\begin{array}{l}\text { Street, address number, type, number of floors, basement, attic, } \\
\text { type of external walls, type of internal walls, basement floor } \\
\text { material, ground floor material, other floors material, attic floor } \\
\text { material, roof covering, roof inclination, draining roof systems, } \\
\text { observations (id_house), (id_geograph), (id_photo) }\end{array}$ & Polygons \\
\hline Roads & Highways, main roads, streets, forestry paths, tracks, bridges & Lines \\
\hline Air transport infrastructures & Airports, heliports, aerodromes, air traffic control towers & Polygons \\
\hline Harbours & Docks, fishing harbours, marinas & Points, polygons \\
\hline Population & People, men, women and families at parish level, (id_geograph) & Points \\
\hline Land use & Urban areas, industrial areas, classified natural areas & Polygons \\
\hline Energy and fuel supply systems & (Geothermal), wind, hydraulic, thermal, fuel & Points, lines, polygons \\
\hline Geothermal infrastructures & $\begin{array}{l}\text { Power plants, pipe lines, (production wells), re-injection wells, } \\
\text { thermometric wells }\end{array}$ & Points, lines \\
\hline Geothermal production wells & Name, altitude, depth, situation, (id_photo) & Points \\
\hline Water supply systems & (Springs), (lakes), (water wells), reservoirs, water lines & Points, lines, polygons \\
\hline Springs & Name, altitude, type, situation, (id_photo) & Points \\
\hline Lakes & Area, altitude, depth, situation, (id_photo) & Polygons \\
\hline Water wells & (Superficial wells), tide wells, (drilled wells) & Points \\
\hline Superficial wells & Name, altitude, depth, situation, (id_photo) & Points \\
\hline Drilled wells & Name, altitude, depth, situation, (id_photo) & Points \\
\hline Telecommunication systems & Towers, antennas, lines for $\mathrm{TV}$, radio and telephones & Points, lines \\
\hline Submarine cables & & Points, lines \\
\hline
\end{tabular}

Table 2. Civil protection data set.

\begin{tabular}{llll}
\hline Layers & Data & & Features type \\
\hline Civil protection headquarters & $\begin{array}{l}\text { People, vehicles, principal equipment, } \\
\text { (id_photo) }\end{array}$ & (id_geograph), & Points \\
Fire headquarters & $\begin{array}{l}\text { People, vehicles, main equipment, (id_geograph), (id_photo) } \\
\text { Emergency data transmission }\end{array}$ & Points \\
links & Towers, repeaters, UHF, freewave, telephone & Points, lines \\
Emergency plans & (id_geograph), (id_bbl) & Points \\
\hline
\end{tabular}

buildings (e.g. houses, public buildings, monuments) were individualized and characterized taking into account several parameters that are crucial to an assessment of their direct vulnerability to geological hazards (e.g. type of construction, number of floors, roof stability).

Resources for civil protection form a specific data set (Table 2) taking into account their importance for emergency response and vulnerability reduction when facing a catastrophic event. In this case all the information related to civil protection and the fire department was considered because these two groups form the core of the Azores Regional Civil Protection Service (SRPCBA).

The geological and geomorphologic data set (Table 3) comprises descriptive and interpretative data obtained from 
Table 3. Geological and geomorphologic data set.

\begin{tabular}{lll}
\hline Layers & Data & Features type \\
\hline Lithology & $\begin{array}{l}\text { Basalts, trachyts, limestone, sandstones, alluvium, beach sand, } \\
\text { beach gravel, clay }\end{array}$ & Polygons \\
Volcanic landforms & $\begin{array}{l}\text { Central volcanoes, cinder cones, spatter cones, spatter ramparts, } \\
\text { pumice cones, tuff cones, maars, domes, spines, lava flow fields, }\end{array}$ & polygons \\
& $\begin{array}{l}\text { caldera rim, crater rim, pit crater, (id_eruption) } \\
\text { Scoria, pumice, lava flows, tephra fall deposits, pyroclastic flow }\end{array}$ & Polygons \\
Volcanic products and deposits & deposits, scoria flows, ignimbrites, block and ash flows, lahars, & \\
& hydrothermal deposits (id_eruption) & Polygons \\
Soils & Ages, dating methods, (id_geology), (id_log) & Points, polygons \\
Stratigraphy & Sample reference number, geochemical analysis, petrographic & Points \\
Samples & data, (id_geology), (id_bbl) & Lines \\
Tectonic features & (Faults), scarp faults & Points, lines \\
Faults & Type, geometry, kinematics, age, dip, plunge, striations, \\
& (id_photo) & Lines, polygons \\
Erosion landforms & Active cliffs, fossil cliffs, valleys, (landslides scars) & Points, polygons \\
Hydrothermal systems & (Fumaroles), degassing areas, thermal springs, cold springs & Points \\
Fumaroles & Name, type, (id_photo) & \\
\hline
\end{tabular}

Table 4. Volcanological data set.

\begin{tabular}{lll}
\hline Layers & Data & Features type \\
\hline Pre-historic volcanic eruptions & $\begin{array}{l}\text { Age, name of eruptive centre, eruption type, (id_geograph), } \\
\text { (id_eruption), (id_geology), (id_photo), (id_log) }\end{array}$ & $\begin{array}{l}\text { Points } \\
\text { Distorical volcanic eruptions } \\
\text { precursory signals, (id_geograph), (id_eruption), (id_geology), } \\
\text { (id_bbl), (id_photo), (id_log) }\end{array}$ \\
Eruptive parameters & $\begin{array}{l}\text { Isopachs, isopleths, (id_eruption), (id_log) } \\
\text { Volcanic eruption impact data }\end{array}$ & $\begin{array}{l}\text { Volcanic hazard, deaths, injured, dislodged people, dam- } \\
\text { aged buildings, others (id_geograph), (id_eruption), (id_bbl), }\end{array}$ \\
& (id_photo) & Points \\
\hline
\end{tabular}

geological mapping surveys and aerial photo analysis (i.e. volcanic, structural and erosion landforms, lithology and tectonic structures; Fig. 2). Additionally, it contains analytical data germane to the petrography and geochemistry of samples related to the established geological units. Geological mapping of the Azores is published at different scales depending on the island $(1: 50000 ; 1: 35000 ; 1: 25000 ; 1: 15000$ and 1:10000) and is being digitized using the new 2001 topographic maps.

Despite the fact that some volcanological data were inserted in the geological and geomorphologic data set it was decided to define a specific volcanological data set (Table 4), to include the information related to the historical volcanic eruptions and their impact. In this group is also considered the information obtained from the study of the eruptive deposits from particular events.

The landslide data set (Table 5) was defined to archive information related to historical and contemporary slope move- ments, as well as their impact. Major historical events are being identified and catalogued based on a detailed study of old documents, while recent occurrences, with preserved scars, are being mapped using aerial photos. Layers for quantitative data related to the morphometric characteristics of landslide scars and associated deposits were also considered.

Taking into account the monitoring networks that are being operated in the Azores archipelago by the Centre of Volcanology and Geological Risk Assessment, data sets for seismology (Table 6), geodesy (Table 7), fluid geochemistry (Table 8) and meteorology (Table 9) were envisaged. In a general way, all these data sets contain information about the characteristics of the monitoring stations, their location and the existing data transmission facilities (Fig. 3). Moreover, they comprise the acquired data, both in their original form and after being processed. Seismological information refers to all the seismic waves, hypocentre parameters and macroseismic data (Fig. 4). Geodetic data includes the GPS 
Table 5. Landslides data set.

\begin{tabular}{lll}
\hline Layers & Data & Features type \\
\hline Landslide events & Date, type of movement, main constituents, trigger, (landslide Points \\
& scar), (landslide deposit), (id_landslide), (id_bbl), (id_photo) & Poximum elevation point, minimum elevation point, maxi- \\
Landslide scar & mum width, average width, perimeter, area, landslide scar, & \\
& (id_landslide) & \\
Landslide deposit & Maximum width, average width, maximum length, average Points, lines, polygons \\
& length, maximum thickness, average thickness, perimeter, area, \\
Landslides impact & volume (id_landslide) & \\
& Deaths, injured, displaced people, damaged buildings, others & Points \\
& (id_geograph), (id_landslide), (id_bbl), (id_photo) & \\
\hline
\end{tabular}

Table 6. Seismological data set.

\begin{tabular}{lll}
\hline Layers & Data & Features type \\
\hline Seismic stations & Station name, type, owner, altitude, station brand, station & Points \\
& model, seismometer brand, seismometer components, fre- & \\
quency, (id_station), (id_photo) & Points, lines \\
Data transmission links & Towers, repeaters, UHF, freewave, telephone & Points \\
Instrumental data & $\begin{array}{l}\text { Date, time, first station, number of stations, epicentre, rms, } \\
\text { depth, Md, ML, type, observations (id_quake) }\end{array}$ & Points \\
Macroseismic data & $\begin{array}{l}\text { Local intensity, intensity scale, deaths, injured, dislodged peo- } \\
\text { ple, damaged buildings, (id_geograph), (id_quake), (id_bbl), }\end{array}$ & Lines, polygons \\
(id_photo) & (id_quake) & \\
\hline
\end{tabular}

observations made with the permanent antennas and during regular field surveys. Fluid geochemistry data consists of $\mathrm{CO}_{2}$ and $\mathrm{H}_{2} \mathrm{~S}$ flux, $\mathrm{CO}_{2}$ concentration, composition of fumaroles and thermal waters, Rn activity, and water wells and lakes physical parameters.

With GIS, data can be accessed and analysed interactively in order to produce new and combined information (Aronoff, 1989). In the present case, risk analysis comprises hazard assessment and vulnerability evaluation using diverse methodologies and precise predicting models. The generated data sets results from spatial, 3-D and geostatistical analysis and are the main frames for risk assessment and management.

\section{Library data sets}

In order to minimize data redundancy without interfering with the performance of the system a codes library was defined, containing specific identification pointers that facilitate the links between layers and data sets (Table 10). Another major set of data that increases the capacity and the utility of AZORIS is the significant collection of available documents that can be automatically displayed from any view. This library data set includes a copy of documents that de- scribe historical catastrophic occurrences related to geological hazards, namely: books; magazines; newspapers; reports and other written information. This includes regional and muni- cipal emergency plans and the alert level codes. Moreover, it provides access to a large set of images like orthophotomaps, photographs, maps, logs and schemes, as well as to useful catalogues (e.g. maps, aerial photographs).

\section{Data archive}

The amount and nature of data that can be acquired, generated and collected, requires a physical support to store information in a structured way. In the present case, the chosen structure (Fig. 5) was thought-out keeping in mind the fact that the geological risk assessment will be carried out at different scales (archipelago, island, county, parish or place), depending on the type and magnitude of the geological event under consideration. Strong earthquakes and high magnitude volcanic eruptions may affect several islands, while minor volcanic events and landslides have an impact in a restricted area within each island. 
Table 7. Geodetic data set.

\begin{tabular}{lll}
\hline Layers & Data & Features type \\
\hline GPS stations & Station name, altitude, station brand, station type, antenna & Points \\
& brand, antenna type, (id_station), (id_photo) & Points, lines \\
Data transmission links & Towers, repeaters, UHF, freewave, telephone & Points \\
GPS benchmark network & Benchmark name, benchmark type, benchmark foundation, net- & Points \\
GPS data & work name, network type (id_station) & Date, $\mathrm{x}, \mathrm{y}, \mathrm{z}, \mathrm{dx}, \mathrm{dy}, \mathrm{dz}$ (id_station) \\
\hline
\end{tabular}

Table 8. Fluid geochemical data set.

\begin{tabular}{|c|c|c|}
\hline Layers & Data & Features type \\
\hline $\mathrm{CO}_{2}$ flux stations & $\begin{array}{l}\text { Station name, altitude, station brand, station type, } \mathrm{CO}_{2} \text { sensor, } \\
\text { (id_station), (id_photo) }\end{array}$ & Points \\
\hline $\mathrm{CO}_{2}$ air concentration stations & $\begin{array}{l}\text { Station name, altitude, station brand, station type, } \mathrm{CO}_{2} \text { sensor, } \\
\text { (id_station), (id_photo) }\end{array}$ & Points \\
\hline $\mathrm{CO}_{2}$ benchmark network & Altitude, benchmark type, (id_station) & Points \\
\hline $\mathrm{H}_{2} \mathrm{~S}$ flux stations & $\begin{array}{l}\text { Station name, altitude, station brand, station type, } \mathrm{H}_{2} \mathrm{~S} \text { sensor, } \\
\text { (id_station), (id_photo) }\end{array}$ & Points \\
\hline Rn stations & $\begin{array}{l}\text { Station name, altitude, station brand, station type, Rn sensor, } \\
\text { (id_station), (id_photo) }\end{array}$ & Points \\
\hline Water well/lake stations & $\begin{array}{l}\text { Station name, altitude, station brand, station type, water level } \\
\text { sensor, temperature sensor, conductivity sensor, (id_station), } \\
\text { (id_photo) }\end{array}$ & Points \\
\hline Data transmission links & Towers, repeaters, UHF, freewave, GSM & Points, lines \\
\hline $\mathrm{CO}_{2}$ data & Date, time, $\mathrm{CO}_{2}$ flux, $\mathrm{CO}_{2}$ concentration, (id_station) & Points \\
\hline $\mathrm{H}_{2} \mathrm{~S}$ flux data & Date, time, $\mathrm{H}_{2} \mathrm{~S}$ flux, (id_station) & Points \\
\hline Rn data & Date, time, Rn, (id_station) & Points \\
\hline Gas geochemical data & $\begin{array}{l}\text { Date, } \mathrm{CO}_{2}, \mathrm{H}_{2} \mathrm{~S}, \mathrm{H}_{2}, \mathrm{CH}_{4}, \mathrm{~N}_{2}, \mathrm{Ar}, \mathrm{O}_{2} \text {, temperature, } \mathrm{pH} \text {, } \\
\text { (id_station) }\end{array}$ & Points \\
\hline Water wells/lakes data & $\begin{array}{l}\text { Date, time, water level, water temperature, water conductivity, } \\
\text { (id_station) }\end{array}$ & Points \\
\hline
\end{tabular}

\section{Metadata}

The definition of Metadata files for the AZORIS data layers became an essential step aiming to guarantee the quality and harmonization of the input data and inform any system user about its quality. Following an analysis of every type of data, in order to assemble all the information needed to describe each data layer, a metadata form was generated with the purpose of validating entry into the system. This metadata file, in a table format, has five main topics.

\subsection{Data ID}

Basic information about the data layer

Name

Responsibility for the creation and update of the file

Date of creation/import

Date of the last update

Comments

\subsection{Data creation}

Information about the origin of the data if it was created outside the system and imported

Author

Reference

Description

\subsection{Data spatial features}

Information on how the spatial elements are displayed Type of unitary elements (vector - point, line, polygon/raster - pixel)

Number of elements

Coordinate system

Reference scale

Area covered

Comments 
Table 9. Meteorological data set.

\begin{tabular}{lll}
\hline Layers & Data & Features type \\
\hline Meteorological stations & Station name, altitude, soil temperature sensor, soil humidity & Points \\
& sensor, barometric pressure sensor, rainfall sensor, wind speed & \\
& sensor, wind direction sensor, air humidity sensor, air tempera- & \\
& ture sensor, (id_station), (id_photo) & Points, lines \\
Data transmission links & Towers, repeaters, UHF, freewave, GSM & Points \\
Meteorological data & Date, time, soil temperature, soil humidity, barometric pressure, & \\
& rainfall, wind speed, wind direction, air humidity, air tempera- & \\
& ture, (id_station) & \\
\hline
\end{tabular}

Table 10. Codes library.

\begin{tabular}{ll}
\hline Codes & Data \\
\hline Bibliographic codes (id_bbl) & Code for each book, paper, magazine, newspaper, report \\
Eruption codes (id_eruption) & Code for each volcanic eruption \\
Earthquakes codes (id_quake) & Code for each earthquake \\
Geographic codes (id_geograph) & Code for islands, counties, cities, villages, parishes, localities, places \\
Geological units codes (id_geology) & Code for geological units such as complexes, groups, formations, members, \\
& $\begin{array}{l}\text { deposits and beds } \\
\text { Houses codes (id_house) }\end{array}$ \\
Landslides codes (id_landslide) & Code for each house \\
Monitoring stations codes (id_station) & Codes for seismological, fluid geochemical, geodetic and meteorological sta- \\
& tions \\
Photo codes (id_photo) & Code for each photo \\
Stratigraphic log codes (id_log) & Code for each stratigraphic log \\
\hline
\end{tabular}

\subsection{Data attributes}

Description of all attributes for each entity in a data layer Name

Type

Range

Description

\subsection{Data quality}

Elements about the quality of the data

Accuracy of spatial features

Accuracy of attributes data

State-of -the-art

Import data method

\section{Conclusions}

The AZORIS database was conceived to archive, manipulate, model and display spatial referenced data for risk analysis. The defined logical and physical dynamic structures allow the system to evolve according to the collected and generated data keeping coherence and enlarging its capabilities. The maintenance of AZORIS will depend on the basic data update taking into account the main parameters that control changes in risk. In order to assure its usefulness, official agreements are being established with regional and local authorities that produce new information.

A major step in the development of the system is related to the application of models for hazard and vulnerability assessment. This will lead to the definition of risk zones based on critical values that can be used for emergency and land-use planning. Another potential of AZORIS results from its link to the monitoring networks operated by the Centre of Volcanology and Geological Risk Assessment. Such potential can be used to implement alarm and warning systems and is of major importance for crisis management.

Acknowledgements. The authors are grateful to D. Chester and J. L. Zêzere for their useful comments and careful manuscript reviewing. This work was carried out within "Project RETINA Realistic Evaluation of Temporal Interaction of Natural Hazards" supported by the UE Contract EVG1-CT-2001-00046 and received a special funding from the SRHE - Azores Regional Government in the scope of "Project CARIGE - Carta de Riscos Geológicos da Região Autónoma dos Açores".

Edited by: R. Couture

Reviewed by: D. Chester and J. L. Zezere 


\section{References}

Aronoff, S.: Geographic Information Systems: a management perspective, Ottawa, WDL Publications, 294, 1989.

Baxter, P., Baubron, J.-C., and Coutinho, R.: Health hazards and disaster potential of ground gas emissions at Furnas volcano, São Miguel, Azores. J. Volcanol. Geotherm. Res., 92, 95-106, 1999.

Cruz-Reyna, S.: Long-term probabilistic analysis of future explosive eruptions, in: Monitoring and Mitigation of Volcano Hazards, edited by Scarpa and Tilling, Springer-Verlag, 599-630, 1996.

Carrara, A., Cardinali, M., Detti, R., Guzzetti, F., Pasqui, V., and Reichenbach, P.: GIS techniques and statistical models in evaluating landslide hazard. Earth Surface Processes and Landforms, Bergamo, Italy, ISMES S.p.A., 16, 5, 427-445, 1991.

Carrara, A., Cardinali, M., Guzzetti, F., and Reichenbach, P.: GIS technology in mapping landslide hazard. Geographical Information Systems in Assessing Natural Hazards, Dordrecht, The Netherlands, Kluwer Academic Publishers, 135-175, 1995.

Carrara, A., Guzzetti, F., Cardinali, M., and Reichenbach, P.: Use of GIS technology in the prediction and monitoring of landslide hazard. Natural Hazards, Dordrecht, The Netherlands, Kluwer Academic Publishers, 20, 117-135, 1999.

Coppock, J.: GIS and natural hazards: an overview from a GIS perspective, in: Geographical Information Systems in Assessing Natural Hazards, edited by Carrara, A. and Guzzetti, F., 21-34, 1995.

Ganas, A. and Papoulia, I.: High-resolution, digital mapping of seismic hazard within the Gulf of Evia Rift, central Greece using normal fault segments as line sources, Natural Hazards, Dordrecht, The Netherlands, Kluwer Academic Publishers, 22, 203-223, 2000.

Gaspar, J. L., Ferreira, T., Malheiro, A. M., Coutinho, R., Trota, A., and Queiroz, G.: Avaliação de perigos geológicos na ilha do Faial após o terramoto de 1998: o caso da freguesia da Ribeirinha, Proceedings do "1 Simpósio de Meteorologia e Geofísica da APMG”, 89-95, 1998.
Jibson, R. W., Harp, E. L., and Michael, J. A.: A method for producing digital probabilistic seismic landslide hazard maps, Engineering Geology, The Netherlands, Elsevier, 58, 271-289, 2000.

Kauahikaua, J., Margriter, S., and Moore, R. B.: GIS-aided volcanic activity hazard analysis for the Hawaii geothermal project environmental impact statement, Natural Hazards, Dordrecht, The Netherlands: Kluwer Academic Publishers, 235-257, 1995.

Pareschi, M. T.: Evaluation of volcanic fallout impact from Vesuvius using GIS, in: GIS for emergency preparedness and health risk reduction, edited by Briggs, D. J., et al., Dordrecht, The Netherlands, Kluwer Academic Publishers, 101-114, 2002.

Pareschi, M. T., Cavarra, L., Favalli, M., Giannini, F., and Meriggi, A.: GIS and volcanic risk management, Natural Hazards, Dordrecht, The Netherlands, Kluwer Academic Publishers, 21, 361-379, 2000.

Salvi, S., Quattrocchi, F., Brunori, C. A., Doumaz, F., Angelone, M., Billi, A., Buongiorno, F., Funiciello, R., Guerra, M., Mele, G., Pizzino, L., and Salvini, F.: A multidisciplinary approach to earthquake research: implementation of a geochemical geographical information system for the Gargano site, southern Italy, Natural Hazards, Dordrecht, The Netherlands, Kluwer Academic Publishers, 20, 255-278, 1999.

Searle, R.: Tectonic pattern of the Azores spreading centre and triple junction, Earth and Planet. Sci. Lett., 51, 415-434, 1980.

Valadão, P., Gaspar, J. L., Queiroz, G., and Ferreira, T.: Landslides density map of S. Miguel island, Azores archipelago, Nat. Haz. Earth Sys. Sc., 2, 1/2, 51-56, 2002.

Van Westen, C. J., Seijmonsbergen, A. C., and Mantovani, F.: Comparing landslide hazard maps, Natural Hazards, Dordrecht, The Netherlands, Kluwer Academic Publishers, 20, 137-158, 1999.

White, M., Schilling, J., and Hart, S.: Evidence for the Azores mantle plume from strontium isotope geochemistry of the central north Atlantic, Nature, 263, 659-663, 1976. 